\section{News@ a glance}

Marburg strikes: Canada sent one of the world's foremost experts on hemorrhagic fevers to Angola, where Marburg virus had infected 200 people, killing 173 as of Apr. 6. Dr. Heinz Feldmann, head of special pathogens program at the National Microbiology Laboratory in Winnipeg, arrived in early April. Feldman and his assistant, laboratory technician Allen Grolla, brought a portable lab; it includes sophisticated DNA analysis equipment but fits into several suitcases and is powered by a car battery. They are part of a team of epidemiologists, infection-control specialists and laboratory experts working under the auspices of WHO. Feldman $\infty$ helped tackle previous outbreaks o of Marburg and Ebola in the Congo and worked in Hong Kong during the SARS outbreak. There is no vaccine or known core against Marburg, which is spread through contact with bodily fluids of infected people.
Public health goals: If you had to define the most effective public health goals, what would you choose? That's the question being put to Canadians by Federal Minister of State for Public Health, Carolyn Bennett during a Canada-wide consultation. The results will be used to align federal policies and health care dollars in ways that promote health. Voice your opinion at www.healthycanadians.ca

Ontario MDs settle: Five months of negotiations between the Ontario government and 24000 physicians ended in late March with a 4-year agreement worth $\$ 2.4$ billion. The new contract increases the province's 24000 doctors' overall pay by $\$ 1.1$ billion by $2007-08$, including a $2.5 \%$ increase for family doctors and $2 \%$ for specialists retroactive to April 2004. It also lifts the billing cap (about $\$ 455000$ annually), provides incentives for physicians to practise in underserviced areas and allows doctors to fully incorporate. Under the 4 year contract, gross pay for specialists will rise $19.5 \%$, while family doctors will gross an additional \$50 000. In November, $59 \%$ of doctors rejected an offer, which included a bonus of $\$ 50$ million if physicians saved the government \$200 million by issuing fewer prescriptions. After that vote, an opinion poll showed that most Ontarians believe doctors put money ahead of health care. The new contract was endorsed by $74 \%$ of physicians, but was opposed by the Specialists' Coalition of Ontario and the Coalition of Family Physicians of Ontario, which says the deal doesn't address the physician shortage.

Autism treatment debate: Ontario's autistic children won the right to public funding for a controversial therapy, only to have the provincial government 
appeal the ruling. The province has been paying for intensive behaviour intervention (IBI) since 2000, but only for children aged 2 to 5. An Ontario Superior Court judge ruled Apr. 1 that denying the children on the basis of age violated their constitutional rights. The one-on-one therapy, which can cost up to $\$ 80000$ annually per child, could cost taxpayers millions. The debate over payment of the treatment has been going on for years. A recent ruling by the Supreme Court of Canada left it up to the provinces to decide what "non-core" services are funded (CMAf 2005;172:168).

Michener finalist: $C M A 7$ and $D e ́-$ couverte, a Radio-Canada science program, were jointly short-listed for the prestigious Michener Award for meritorious public service in journalism for coverage of the outbreak of Clostridium difficile infection in Quebec hospitals. The 6 finalists for the award included the Globe and Mail, which

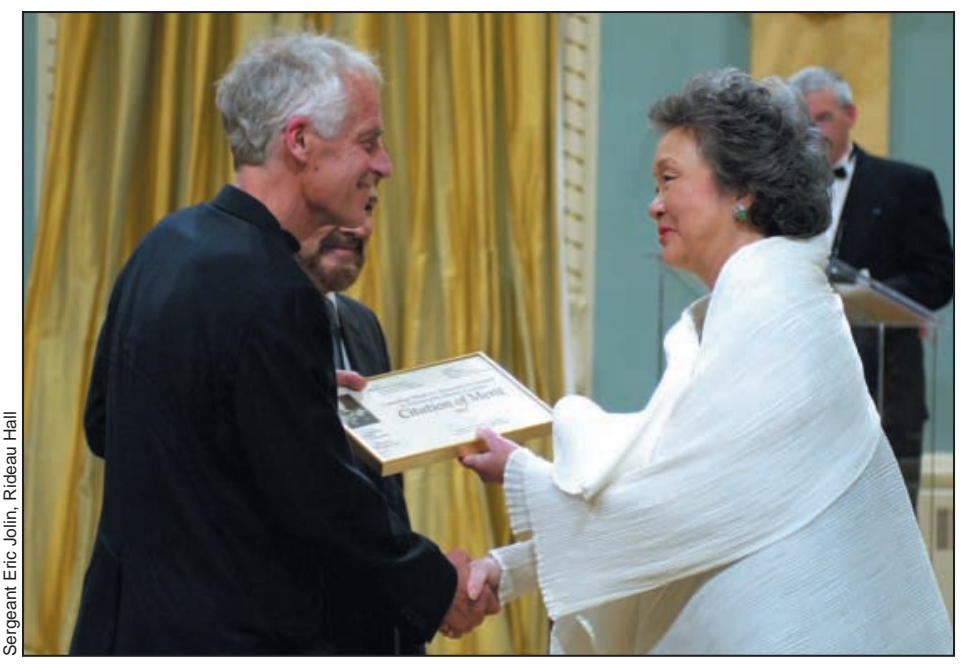

won for its investigation into the Liberal sponsorship scandal. "We were honoured to be shortlisted for this important award," said CMA7 editor Dr. John Hoey, pictured above accepting a Citation of Merit from the Governor General at a ceremony Apr. 14 at Rideau Hall. CMAf reporters Laura Eggertson and Barbara Sibbald broke the $C$. difficile story in June with their report that at least 79 patients had died of the infection. As a result, the Quebec Ministry of Health struck a committee of experts, which recommended a number of changes to hospital protocols, and later formed a surveillance committee. The Public Health Agency of Canada subsequently launched a surveillance program at 25 major Canadian hospitals. - Compiled by Barbara Sibbald, CMAJ 